\title{
Municipal Waste Map: a Case Study of Guimarães, Portugal
}

\author{
Dalila Sepúlveda ${ }^{1}$, Isabel Loureiro ${ }^{2}$, Cândida Vilarinho ${ }^{3}$, Joana Carvalho ${ }^{3,4^{*}}$
}

\begin{abstract}
Guimarães is located in the north of Portugal, is a middle size town, which historic centre is UNESCO World Heritage. The city was also European Cultural Capital by 2012 and in 2013 was European City of Sports. Currently, is running for European Green Capital 2020, being the Waste Production and Management (WPM) one of the strategic guideline. Taking into account the WPM policy and the city goals, a Municipality Strategic Waste Plan (2016-2025) (SWP), will be done. Guimarães is considered to be a "diffuse territory", as it encompasses land use and economic activity development, leading to different scenarios. It is also important to notice that $1 / 3$ of the Guimarães population is located on the urban area. Under this context, the WPM across the Municipality will be directly affected by specific features of the urban population, and the correlation between several other variables shall be considered in a holistic approach comprising waste production characterization, land use, citizens socio demographic aspects and human resources. This project aims at presenting a first approach to the definition of the SWP, in the form of an integrated Roadmap of waste production, in a multi-disciplinary approach between the land use and the sociodemographic characteristics.
\end{abstract}

Keywords: Waste Management Plan, holistic approach, Municipal waste.

\section{Introduction}

Guimarães, is a city and municipality located in northern Portugal, in the district of Braga. It is also a part of the Ave Subregion (one of the most industrialised subregions in the Portugal), as well as the historical Minho Province. is a middle size town with 158000 inhabitants, which historic centre belongs to UNESCO World Heritage (figure 1). According to 2011 Census, Guimarães has 158124 inhabitants distributed by 240.955 $\mathrm{Km} 2$. In terms of administrative organization, the territory has 48 parishes, with a group of 17 medium size agglomerations, and 31 that can be considered to be small size. The city was also European Cultural Capital by 2012 and European City of Sports in 2013. Guimarães was elected by the New York Times one of the 41 places to go in 2011 and NYT called it one of the Iberian peninsula's emerging cultural spots. Currently, is running for European Green Capital 2020 award and therefore aiming at defining a sustainable strategic plan foreseeing city development. According to Zotos et. al (2008), local authorities play an important role in supporting changes towards sustainable development, being responsible for the infrastructure development, public involvement,

${ }^{1}$ City Hall of Guimarães

2ALGORITMI Centre of University of Minho

${ }^{3} \mathrm{CT} 2 \mathrm{M}$ of University of Minho

${ }^{4}$ CVR- Centro para Valorização de Resíduos

*Corresponding author: 
education and social welfare promotion. The European Commission defined 12 important areas for sustainable development [2] being Waste Production and Management one of them.

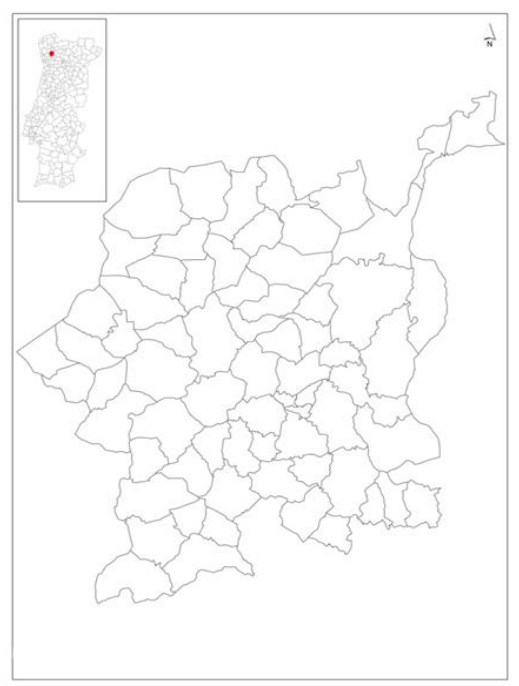

Figure 1: Localization of Guimarães

In the new legislation framework enacted by the European Union (EU), the characterization of municipal solid waste (MSW) represents an important instrument for local governments and sanitation operators in setting and achieving targets for waste recycling and recovery. Taking into account the EU policy on waste management (EU Waste Framework Directive, 2008/98/EC) and the city goals towards a "greener" and sustainable territory, several measures are planned for Municipal Waste Management (MWM) improvement, including waste reduction, collection and transfer, composting, incineration, landfills, special wastes, waste characterization, management and planning, training, public education and financing. These actions will be enclosed on the Strategic Waste Plan (SWP) for Guimarães (2016-2025), in close relation to city context and scenarios (Sahimaa et. al (2008)). According to Di Maria and Micale (2014), the identification of local factors such as social, technical, economic and environmental aspects, should be integrated, for a coherent and sustainable waste management program. Guimarães is considered to be a "diffuse territory", as it encompasses land use and economic activity development, leading to different scenarios. Three types of land use can be identified as follows, agriculture; forest area and infrastructures implementation for industrial activities (textile, footwear and cutleries). An intense agricultural practice, strongly related to soil characteristics and water lines location, can be found. It is also important to notice that $1 / 3$ of the Guimarães population is located on the urban area, where most of the services and equipment are implemented, while the remaining $2 / 3$ is placed outside the central agglomeration, an area registered for both, industrial activity and agricultural practices.

According to Suthar and Singh (2014), a holistic approach is required, comprising waste 
production characterization, land use, citizens' socio demographic aspects and human resources. Taking Guimarães as reference, it is considered that waste production across the Municipality will be directly affected by certain characteristics, such as the buying capacity, the rural vs. industrial waste provenience, and the citizens' socio-demographic, their attitudes and behaviors, among others.

The main objective of this paper is to determine the first step of the SWP, consisting in identifying the household waste (HW), resulting from the principal circuits of the regular waste routes. As result, a first draft of the Municipal Waste Map will be presented, in the form of an integrated Roadmap of waste production, in a multi-disciplinary approach between the land use and the socio-demographic characteristics.

\section{Principal activities for the definition of a Municipal Waste Plan - waste composition}

Planning a SWP is a complex process, as it must include many factors. Municipal solid waste management is a multidisciplinary activity, that includes waste generation, source separation, storage, collection, transfer and transportation, processing and recovery, and final disposal (Das and Bhattacharyya, 2015; Bovea et al., 2010; Gallardo et al., 2015). Among the different activities involved in the management of MWM, collection is one of the most relevant, due to both the operation costs and the potential impact on the life quality under the urban context.

According to Gallardo et al. (2015), collection can account for up to $70 \%$ of the whole waste management costs. In Guimarães this cost is lower, as the pre-collection and the collections routes share $50 \%$ of the budget of the Municipality Waste Management system. Collection is the activity that comprises the transport of the urban waste from the houses (primary disposal) to a treatment plant. This process includes human resources, the trash car collection, the time and distance of the collection route, so this activity has to be as much optimized as possible. Additionally, the role of the citizens in this stage will also be as important as the optimization system, so the social factors must be included when the waste management map is being designed. The collection system in Guimarães is made by predefined circuits with a predetermined frequency; the most representative system is the door-to-door lost bag; the estimated annual production is about 56000 ton of urban waste and 7000 ton of recycling materials and the per capita production is about $1.0 \mathrm{~kg} /$ person/day.

The quantification and characterization of HW should be the first thing to do in order to design a SWP. HW has a heterogeneous composition, comprising a variety of wastes of different chemical and biological nature (Suthar and Singh, 2014). The prediction of municipal solid waste (MSW) generation plays an important role in solid waste management (SWM) (Dyson and Chang, 2005). The aim of this article is to provide a proper basis for developing clear and realistic forecasts in current municipal waste management, based on the MSW composition. This will lead to practical solutions for successfully meeting the main objectives concerning the pre-collection /collection/treatment/recovery/disposal of the waste material group, types of settlements and the number of inhabitants, all to meet the target for the definition of the Municipal Waste Plan. 
The amount and composition of waste provides the basic information needed for the planning, operationalization and optimization of waste management systems (Beiglet et al., 2008). Information on the composition of mixed MSW is needed in the planning and environmental assessment of waste management (Edjabou et al., 2015). Characterization of MSW composition usually consists in separated waste from the cars of collective routes, followed by sorting the waste into a number of material fractions, ending with the interpretation of the obtained data. There are several factors, such as physical, geographical, socio-cultural, economic and political ones which influence the composition and generation of MSW (Gallardo et al., 2015). One of the factors to be taken into account in the waste characterization is the season. This is due to alterations in MSW generation and composition depending on the climate and the time of the year. Gómez et al. (2009) pointed out that the smallest amount of MSW appears when temperatures are lower. The type of city must also be taken into account as there are differences in waste generation depending on the main activity of the zone. According Zaman and Lehmann (2011), this activity can be classified as residential, commercial, institutional or industrial. According to Suthar and Singh (2014), the quantification and characterization of HW should be done in order to design an effective waste collection and waste management plan for the residential block of the city. The knowledge of MSW physical composition and evolution is crucial to planning the methods and technologies to be applied as treatment. An understanding of the physical characterization of the wastes is also crucial to determine a typical MSW, in order to evaluate indicators such as the potential and the rates of recovery and recycling of materials such as packaging waste (Magrinho et al., 2006). According to Lisa and Anders (2008), the general procedure in most of the standard methods for HW composition studies follows the four steps:

1. Planning and design of the analyses.

2. Sampling and sample splitting.

3. Manual sorting and classification of components.

4. Evaluation and processing of the data.

\section{Methodology}

The characterization of MSW was performed according to Sahimaa et al. (2008) methodology considering the Portuguese law requirements Portaria n. ${ }^{\circ} 851 / 2009$, 7 th August [7].

The sampling techniques were established based on statistical research; a guide for determining the composition of MSW and the generation index was developed together with the necessary regulations for inclusion/exclusion of tests; this guide detailed the procedure for collecting and sorting waste; research in the field for sampling from the population, taking into consideration: location type (urban, rural); number of inhabitants; coverage of sanitation services in communities; laboratory analysis of samples from all working points were performed according to an established methodology. The waste composition was determined taking into consideration all of the above, and the MSW composition per individual material group was presented, based on weight, volume, type of substance, weighing tolerance, container volume, statistical errors in calculation $(<0,5 \%)$. 
According to the methodology, twenty-nine circuits, from regular collection routes will be analyzed, and the obtained data was interpreted, to develop more accurate local waste management systems, including the end-of-life valorization routes. In order to characterize the population, results from Pina (2015) study were used. Several maps were produced for a wide view of territory characteristics according to land use, frequency of collection routes and bin equipment. The methodology comprises an initial MSW characterization for a period between 12 to 20th April 2016. The sampling campaign covered residual waste collected from all over the town. Guimarães has 35 different waste routes, 31 from door-to-door system, for which the municipality is responsible and 4 from underground waste containers, which responsibility belongs to VITRUS, a public company. The door-in-door routes are divided in morning and night schedule, considering the type of land uses, such as: residential, commercial, industrial and agriculture use, the density of population, and the type of roads (figure 2). The methodology involved collecting solid waste directly from the collective routes according to law requirements [7] and only includes the door-in-door routes, and the underground waste containers, being excluded from this study the selective routes. The characterization was undertaken by Centre for Waste Valorisation (CVR), a nonprofit institution that offers research, scientific analysis and actual application services in the waste valorization area. The main fractions obtained were: Organic food, gardening waste, paper, board, plastic, metal, glass, miscellaneous combustibles, textiles, special waste, inert and wood.

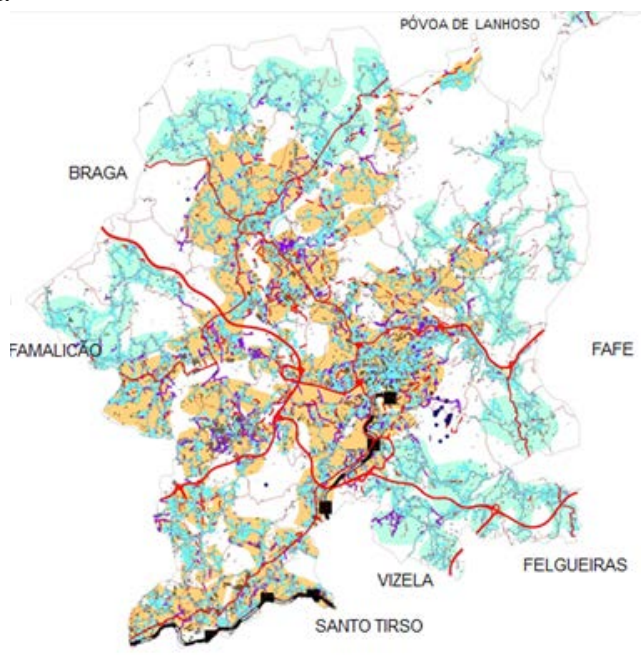

Figure 2. Delimitation of Urban area in Guimarães

Each waste sample had $350 \mathrm{~kg}$. Three types of urban areas were considered, according to INE (2014) databases: urban (residential, commercial and institutional), mix (residential, industry and rural) and rural (residential and rural), helping to establish the frequency and the capacity for the vehicle used on waste collection. The Municipality has a total of 35circuits comprising all the 48 parishes. A total of 29 routes were used for the Municipality waste characterization. These routes were sorted and numbered according to Table 1. Period and frequency regarding waste collection, and the type of Urban Area 
were also considered. Similar routes were not used as criteria for routes selection.

Table 1. Waste circuits routes

\begin{tabular}{lllll}
\hline $\begin{array}{l}\text { Numb } \\
\text { er }\end{array}$ & Period & Frequency & $\begin{array}{l}\text { type of } \\
\text { Area }\end{array}$ & $\begin{array}{c}\text { Urban } \\
\text { Characterizati } \\
\text { on }\end{array}$ \\
\hline 1A & Morning & 3 times a week & Mix & yes \\
1B & Morning & 3 times a week & Rural & yes \\
2A & Morning & 3 times a week & Mix & yes \\
2B & Morning & 3 times a week & Mix & yes \\
3A & Morning & 3 times a week & Rural & yes \\
3B & Morning & 3 times a week & Rural & yes \\
4a & Morning & 3 times a week & Rural & yes \\
4B & Morning & 3 times a week & Mix & yes \\
$5^{\text {a }}$ & Morning & 3 times a week & Urban & yes \\
5B & Morning & 3 times a week & Mix & yes \\
$6^{\text {a }}$ & Morning & 3 times a week & Mix & yes \\
6B & Morning & 3 times a week & Urban & yes \\
$7^{\text {a }}$ & Morning & 3 times a week & Rural & no \\
7B & Morning & 3 times a week & Urban & yes \\
$8^{\text {a }}$ & Morning & 3 times a week & Mix & yes \\
8B & Morning & 3 times a week & Mix & yes \\
10 & Night & 3 times a week & Mix & yes \\
10B & Night & 3 times a week & Mix & no \\
11 & Night & 3 times a week & Urban & yes \\
11B & Night & 3 times a week & Mix & yes \\
12 & Night & 3 times a week & Urban & yes \\
12B & Night & 3 times a week & Urban & no \\
13 & Night & 3 times a week & Mix & yes \\
13B & Night & 3 times a week & Mix & yes \\
14 & Night & 3 times a week & Rural & yes \\
14B & Night & 3 times a week & Mix & yes \\
15B & Night & 3 times a week & Mix & yes \\
16B & Night & 3 times a week & Urban & yes \\
17 & Night & diary & Urban & yes \\
\hline & & &
\end{tabular}

In addition to the referred routes, three underground waste containers routes were also considered for analysis. These containers called "moloks" have a higher capacity, between 3000 and 50001 as they are placed in urban areas with high population density. The performed characterization was very extensive in order to analyze the whole quantity of waste in the survey area (parent population). Regarding the sampling area, samples have to be representative and should describe the characteristics of the whole parent population. The composition of household/commercial waste is heterogeneous consisting of many different components or categories. Furthermore, the size of waste particles ranges from $\mathrm{mm}$ (fine elements) up to $1 \mathrm{~m}$ (e.g. parts of furniture). In order to obtain statistically acceptable results for such heterogeneous conditions it is necessary to analyze a suitable sample size [18]. Results from a study conducted by Pina about the characterization of the population (Pina, 2015), were used. The results were based on a questionnaire applied on a stratified random sampling comprising ten of the 48 parishes: 
Ronfe, Brito, Serzedelo, Caldelas, Ponte, Selho S. Jorge, Moreira, S. Torcato e Lordelo and União de Freguesias de Oliveira do Castelo, S. Paio and S. Sebastião. No missing values were obtained, indicating that the questionnaire was a feasible observation tool (sensitivity equal to 100\%). This study surveyed 804 people representing a sampling error of 5\% (Pina, 2015).

\section{Results}

The average waste composition is depicted on figure 3, showing a very high percentage from recyclable materials that are included in $\mathrm{HW}$, which it is not separated. Almost half of waste composition corresponds to Food waste, and fines (44\%). Plastic represents $12 \%$ paper and cardboard (11\%) and human hygiene waste about $6 \%$. It is also important to remark that textiles represents $5.32 \%$ of the total waste composition, mainly due to the existence of small industries that does not have implemented waste separation for this kind of materials, mixing it with the common waste. The proportion of recyclable material fractions mixed in urban collect represents more than $30 \%$. Concerning the moister content, all the door in door routes has humidity higher than $55.0 \%$, with almost being between the range $75.0-85.0 \%$, only the containers circuits have lower humidity.

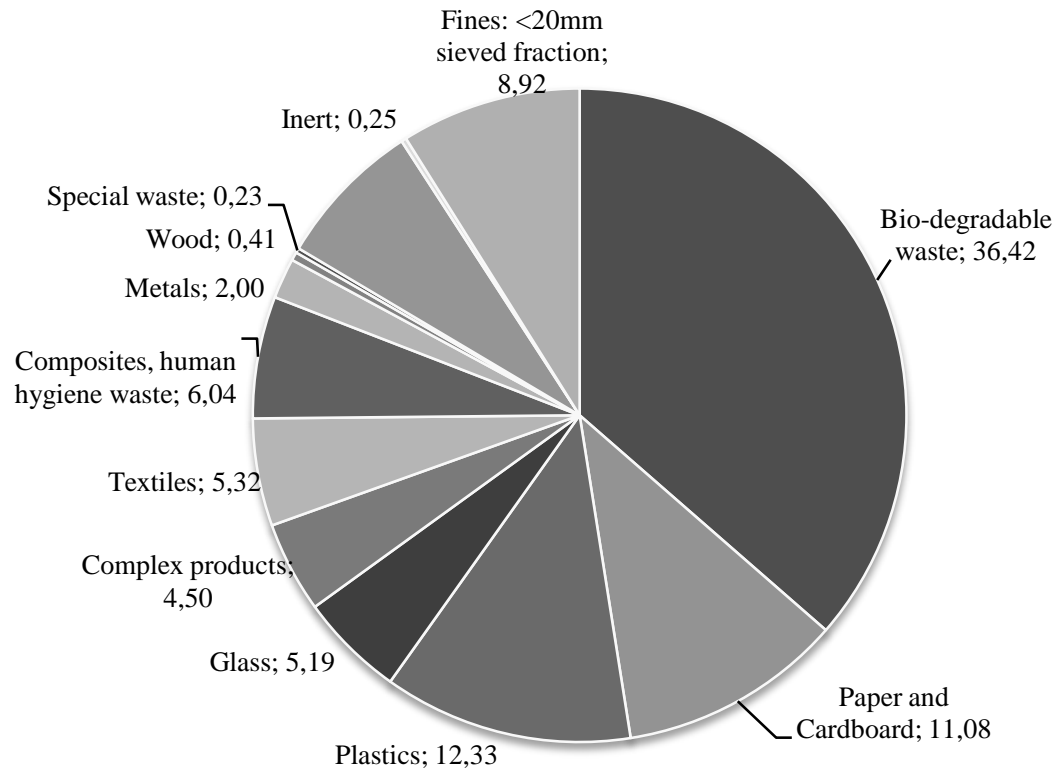

Figure 3. Composition (based upon average value) of household waste in all collection routes.

There were statistically significant variations $(\mathrm{p}<0.05)$ among different locations in the city for HW composition, the reason why it is important to study each route, analyzing the composition in each town.

According to Pina (2015) a significant percentage of the respondents do, in fact, waste recycling $(72.6 \%)$ whereas only $10 \%$ are dissatisfied with the municipal waste services. Furthermore, the recycling point is located less than $200 \mathrm{~m}$ from the residence $(64.3 \%)$ 
which seems to contribute to increase the waste recycling, but these results should be higher considering the results of the characterization made by CVR. Results showed by Pina (2015) evidence that population of Ponte (route 7B) is not so aware of the waste recycling as Brito (route 6B), Caldelas (route 14B), Moreira de Cónegos (route 2B), Oliveira do Castelo (route 17) and Ronfe (route 4B), however most of the respondents were aware for waste recycling, comparing to the results of waste composition we noticed that is not coincident, because in that routes we have results between $19 \%$ to $40 \%$ of recycle waste mixed in HW. Results from the characterization also suggested that approximately three quarters of MSW is composed of recyclable materials. According to the Wastes Work and AEA (2010) several factors can have influence these results, namely

- Socio-economic profile of the households - the potential impact of household socio-economic.

- Urban or rural location - difference between waste arising in urban and rural areas.

Seasonal variation - A comparison of the average summer and winter results for household residual waste.

In order to optimize routes, to develop new recycling routes, and to install news ecopoints, a careful analysis was also conducted regarding composition per route/circuit (table 4, table 5 and table 6).

Table 2. Composition per circuit between 1A-5B (\%)

\begin{tabular}{|c|c|c|c|c|c|c|c|c|c|c|}
\hline Type & $\begin{array}{l}1 \mathrm{~A} \\
\%\end{array}$ & $\begin{array}{l}1 \mathrm{~B} \\
\%\end{array}$ & $\begin{array}{l}2 \mathrm{~A} \\
\%\end{array}$ & $\begin{array}{l}2 \mathrm{~B} \\
\%\end{array}$ & $\begin{array}{l}3 \mathbf{A A} \\
\%\end{array}$ & $\begin{array}{l}3 \mathrm{~B} \\
\%\end{array}$ & $\begin{array}{l}4 \mathbf{A} \\
\%\end{array}$ & $\begin{array}{l}4 \mathrm{~B} \\
\%\end{array}$ & $\begin{array}{l}\mathbf{5 A} \\
\%\end{array}$ & $\begin{array}{l}5 \text { B } \\
\%\end{array}$ \\
\hline Bio-degradable waste & 34.3 & 54.3 & 31.1 & 45.9 & 29.4 & 15.1 & 18.8 & 36.0 & 41.3 & 50.9 \\
\hline Food waste & 16.1 & 18.3 & 6.4 & 15.1 & 10.9 & 4.9 & 2.2 & 12.4 & 10.9 & 7.2 \\
\hline Gardening waste & 3.3 & 7.5 & 2.8 & 4.4 & 0.4 & 0.0 & 8.1 & 14.0 & 12.6 & 5.5 \\
\hline $\begin{array}{l}\text { Other biodegradable } \\
\text { waste }\end{array}$ & 14.9 & 28.5 & 21.8 & 26.5 & 18.2 & 10.2 & 8.4 & 9.6 & 17.8 & 38.2 \\
\hline Paper and Cardboard & 11.3 & 7.2 & 14.9 & 8.4 & 9.6 & 5.8 & 14.9 & 10.0 & 6.8 & 7.2 \\
\hline Paper/card - packaging & 1.2 & 4.7 & 8.9 & 3.3 & 3.9 & 1.4 & 3.0 & 2.7 & 2.0 & 0.9 \\
\hline $\begin{array}{l}\text { Newspapers and } \\
\text { magazines }\end{array}$ & 4.8 & 0.9 & 1.1 & 1.2 & 1.1 & 0.0 & 5.4 & 3.4 & 1.6 & 2.3 \\
\hline $\begin{array}{l}\text { Other Paper/card- non } \\
\text { packaging }\end{array}$ & 5.4 & 1.6 & 4.9 & 3.9 & 4.5 & 4.4 & 6.5 & 3.8 & 3.2 & 4.0 \\
\hline Plastics & 9.9 & 11.5 & 11.5 & 11.6 & 11.6 & 10.7 & 13.4 & 11.8 & 10.3 & 9.5 \\
\hline Plastic film PE & 6.6 & 7.9 & 8.0 & 7.6 & 8.0 & 4.1 & 9.2 & 7.3 & 7.1 & 5.8 \\
\hline Packaging plastic PET & 1.3 & 1.7 & 0.9 & 0.8 & 1.0 & 0.3 & 1.0 & 1.7 & 1.1 & 1.6 \\
\hline Packaging plastic PEAD & 0.6 & 1.1 & 1.6 & 2.4 & 2.2 & 1.1 & 2.2 & 1.3 & 1.5 & 1.3 \\
\hline Packaging plastic EPS & 0.0 & 0.1 & 0.0 & 0.0 & 0.0 & 0.1 & 0.2 & 0.0 & 0.1 & 0.2 \\
\hline Non-packaging plastic & 0.7 & 0.6 & 0.7 & 0.4 & 0.3 & 0.7 & 0.8 & 0.9 & 0.5 & 0.7 \\
\hline Other plastic resins & 0.7 & 0.2 & 0.4 & 0.3 & 0.1 & 4.5 & 0.0 & 0.6 & 0.0 & 0.0 \\
\hline Glass & 7.4 & 8.4 & 4.7 & 0.9 & 7.6 & 24.2 & 2.5 & 4.3 & 3.7 & 4.5 \\
\hline $\begin{array}{l}\text { Packaging container } \\
\text { glass }\end{array}$ & 6.9 & 8.4 & 4.0 & 1.8 & 6.4 & 0.0 & 2.5 & 4.3 & 3.7 & 4.5 \\
\hline Other/special glass & 0.5 & 0.0 & 0.7 & 0.0 & 1.2 & 24.2 & 0.0 & 0.0 & 0.0 & 0.0 \\
\hline Complex products & 3.0 & 2.8 & 7.5 & 3.1 & 3.7 & 1.3 & 6.4 & 3.9 & 3.6 & 2.8 \\
\hline $\begin{array}{l}\text { Composite/Complex } \\
\text { Packaging }\end{array}$ & 0.3 & 1.4 & 0.4 & 1.0 & 1.8 & 0.3 & 2.7 & 1.1 & 0.9 & 1.4 \\
\hline $\begin{array}{l}\text { Composite/other } \\
\text { Complex Packaging }\end{array}$ & 1.4 & 0.8 & 3.2 & 1.6 & 1.6 & 0.9 & 1.8 & 2.2 & 1.7 & 1.5 \\
\hline
\end{tabular}




\begin{tabular}{|c|c|c|c|c|c|c|c|c|c|c|}
\hline Type & $\begin{array}{l}1 \mathrm{~A} \\
\%\end{array}$ & $\begin{array}{l}\mathrm{B} \\
\%\end{array}$ & $\begin{array}{l}2 \mathrm{~A} \\
\%\end{array}$ & $\begin{array}{l}2 \mathrm{~B} \\
\%\end{array}$ & $\begin{array}{l}3 \mathrm{~A} \\
\%\end{array}$ & $\begin{array}{l}3 \mathrm{~B} \\
\%\end{array}$ & $\begin{array}{l}\mathrm{A} \\
\%\end{array}$ & $\begin{array}{l}4 \mathrm{~B} \\
\%\end{array}$ & $\begin{array}{l}5 \mathrm{~A} \\
\%\end{array}$ & $\begin{array}{l}5 \text { B } \\
\%\end{array}$ \\
\hline WEEE & 0.3 & 0.0 & 0.0 & 0.0 & 0.0 & 0.0 & 0.0 & 0.3 & 0.0 & 0.0 \\
\hline Mixed WEEE & 1.0 & 0.6 & 3.9 & 1.4 & 0.3 & 0.0 & 1.9 & 0.3 & 1.0 & 0.0 \\
\hline Textiles & 2.0 & 0.3 & 5.3 & 0.9 & 7.8 & 27.5 & 3.2 & 3.3 & 8.7 & 2.7 \\
\hline Non-clothing textiles & 0.0 & 0.0 & 0.0 & 0.0 & 0.0 & 0.0 & 0.0 & 0.0 & 0.0 & 0.0 \\
\hline Others textiles & 2.0 & 0.3 & 5.3 & 0.9 & 7.8 & 27.5 & 3.2 & 3.3 & 8.7 & 2.7 \\
\hline $\begin{array}{l}\text { Composites, human } \\
\text { hygiene waste }\end{array}$ & 3.8 & 0.0 & 5.4 & 7.5 & 12.3 & 3.2 & 9.4 & 16.4 & 4.0 & 10.6 \\
\hline Metals & 1.5 & 1.2 & 0.9 & 2.7 & 4.2 & 0.7 & 1.1 & 2.2 & 0.8 & 1.0 \\
\hline Ferrous Packaging & 1.1 & 0.7 & 0.6 & 1.2 & 3.7 & 0.5 & 0.9 & 0.6 & 0.8 & 0.8 \\
\hline Non-ferrous Packaging & 0.4 & 0.5 & 0.1 & 1.0 & 0.5 & 0.2 & 0.2 & 0.6 & 0.0 & 0.2 \\
\hline Miscellaneous Ferrous & 0.0 & 0.0 & 0.0 & 0.0 & 0.0 & 0.0 & 0.0 & 0.0 & 0.0 & 0.0 \\
\hline Other metallic waste & 0.0 & 0.0 & 0.2 & 0.5 & 0.0 & 0.0 & 0.0 & 1.1 & 0.0 & 0.0 \\
\hline Wood & 0.6 & 0.0 & 0.2 & 2.0 & 0.0 & 0.0 & 0.0 & 0.8 & 0.0 & 0.0 \\
\hline Untreated Wood & 0.0 & 0.0 & 0.0 & 0.0 & 0.0 & 0.0 & 0.0 & 0.8 & 0.0 & 0.0 \\
\hline Other & 0.6 & 0.0 & 0.2 & 2.0 & 0.0 & 0.0 & 0.0 & 0.0 & 0.0 & 0.0 \\
\hline Special waste & 0.2 & 0.0 & 0.3 & 0.0 & 0.0 & 0.0 & 0.0 & 0.2 & 0.0 & 0.0 \\
\hline Quimical products & 0.2 & 0.0 & 0.0 & 0.0 & 0.0 & 0.0 & 0.0 & 0.0 & 0.0 & 0.0 \\
\hline Mixed WEEE & 0.0 & 0.0 & 0.0 & 0.0 & 0.0 & 0.0 & 0.0 & 0.1 & 0.0 & 0.0 \\
\hline $\begin{array}{l}\text { Single Batteries/non- } \\
\text { device specific Batteries }\end{array}$ & 0.0 & 0.0 & 0.1 & 0.0 & 0.0 & 0.0 & 0.0 & 0.1 & 0.0 & 0.0 \\
\hline $\begin{array}{l}\text { Other household } \\
\text { hazardous waste }\end{array}$ & 0.0 & 0.0 & 0.1 & 0.0 & 0.0 & 0.0 & 0.0 & 0.0 & 0.0 & 0.0 \\
\hline $\begin{array}{l}\text { Gardening waste } \\
\text { (collect separately) }\end{array}$ & 15.5 & 0.0 & 7.6 & 9.3 & 8.0 & 0.0 & 16.7 & 2.9 & 12.0 & 5.4 \\
\hline Inert & 0.0 & 0.0 & 0.0 & 0.0 & 0.0 & 7.2 & 0.0 & 0.0 & 0.0 & 0.0 \\
\hline $\begin{array}{l}\text { Fines: }<20 \mathrm{~mm} \text { sieved } \\
\text { fraction }\end{array}$ & 10.6 & 14.3 & 10.6 & 7.7 & 5.9 & 4.4 & 13.7 & 8.3 & 8.8 & 5.3 \\
\hline
\end{tabular}

Table 3. Composition per circuit between 6A-13A

\begin{tabular}{|c|c|c|c|c|c|c|c|c|c|c|}
\hline Type & $\begin{array}{l}6 \mathrm{~A} \\
\%\end{array}$ & $\begin{array}{l}6 \mathrm{~B} \\
\%\end{array}$ & $\begin{array}{l}7 \mathrm{~B} \\
\%\end{array}$ & $\begin{array}{l}8 \mathbf{A} \\
\%\end{array}$ & $\begin{array}{l}8 \mathrm{~B} \\
\%\end{array}$ & $\begin{array}{l}10 \mathrm{~A} \\
\%\end{array}$ & $\begin{array}{l}11 \mathrm{~A} \\
\%\end{array}$ & $\begin{array}{l}11 \mathrm{~B} \\
\%\end{array}$ & $\begin{array}{l}12 \mathrm{~A} \\
\%\end{array}$ & $\begin{array}{l}13 \mathrm{~A} \\
\%\end{array}$ \\
\hline $\begin{array}{l}\text { Bio-degradable } \\
\text { waste }\end{array}$ & 33.1 & 43.4 & 27.3 & 34.8 & 14.0 & 50.5 & 25.1 & 22.7 & 34.6 & 47.0 \\
\hline Food waste & 13.6 & 15.7 & 21.3 & 12.6 & 4.0 & 15.4 & 3.7 & 14.1 & 8.6 & 16.0 \\
\hline Gardening waste & 5.3 & 6.0 & 6.0 & 13.2 & 10.1 & 2.8 & 10.0 & 4.7 & 2.3 & 0.0 \\
\hline $\begin{array}{l}\text { Other biodegradable } \\
\text { waste }\end{array}$ & 14.2 & 21.8 & 0.0 & 9.1 & 0.0 & 32.3 & 11.5 & 3.9 & 23.7 & 30.9 \\
\hline $\begin{array}{ll}\text { Paper and } & \text { and } \\
\text { Cardboard } & \end{array}$ & 12.0 & 11.8 & 12.8 & 10.0 & 23.0 & 10.2 & 13.1 & 12.0 & 7.5 & 8.4 \\
\hline $\begin{array}{l}\text { Paper/card } \\
\text { packaging }\end{array}$ & 3.1 & 3.8 & 3.4 & 2.4 & 3.9 & 3.7 & 6.8 & 0.9 & 4.7 & 1.7 \\
\hline $\begin{array}{l}\text { Newspapers and } \\
\text { magazines }\end{array}$ & 3.5 & 4.4 & 6.8 & 4.7 & 4.3 & 3.8 & 3.6 & 1.4 & 1.5 & 3.9 \\
\hline $\begin{array}{l}\text { Other Paper/card- } \\
\text { non packaging }\end{array}$ & 5.4 & 3.6 & 2.6 & 2.8 & 14.8 & 2.7 & 2.6 & 9.7 & 1.2 & 2.7 \\
\hline Plastics & 9.9 & 13.5 & 17.2 & 13.3 & 11.6 & 10.9 & 13.7 & 13.7 & 12.6 & 12.3 \\
\hline Plastic film PE & 5.8 & 8.9 & 8.4 & 8.4 & 8.8 & 5.8 & 6.9 & 7.2 & 6.3 & 8.0 \\
\hline $\begin{array}{l}\text { Packaging plastic } \\
\text { PET }\end{array}$ & 0.8 & 1.1 & 5.3 & 1.1 & 0.9 & 1.7 & 2.2 & 1.7 & 3.4 & 1.1 \\
\hline $\begin{array}{l}\text { Packaging plastic } \\
\text { PEAD }\end{array}$ & 1.1 & 2.3 & 2.6 & 2.1 & 1.2 & 1.6 & 2.5 & 1.5 & 1.2 & 1.9 \\
\hline
\end{tabular}




\begin{tabular}{|c|c|c|c|c|c|c|c|c|c|c|}
\hline Type & $\begin{array}{l}6 \mathrm{~A} \\
\%\end{array}$ & $\begin{array}{l}6 \mathrm{~B} \\
\%\end{array}$ & $\begin{array}{l}7 \mathrm{~B} \\
\%\end{array}$ & $\begin{array}{l}8 \mathrm{~A} \\
\%\end{array}$ & $\begin{array}{l}8 \mathrm{~B} \\
\%\end{array}$ & $\begin{array}{l}10 \mathrm{~A} \\
\%\end{array}$ & $\begin{array}{l}11 \mathrm{~A} \\
\%\end{array}$ & $\begin{array}{l}11 \mathrm{~B} \\
\%\end{array}$ & $\begin{array}{l}12 \mathrm{~A} \\
\%\end{array}$ & $\begin{array}{l}13 \mathrm{~A} \\
\%\end{array}$ \\
\hline $\begin{array}{l}\text { Packaging plastic } \\
\text { EPS }\end{array}$ & 0.0 & 0.5 & 0.2 & 0.1 & 0.0 & 0.3 & 0.7 & 0.6 & 0.5 & 0.0 \\
\hline $\begin{array}{l}\text { Non-packaging } \\
\text { plastic }\end{array}$ & 1.1 & 0.7 & 0.8 & 0.8 & 0.4 & 0.7 & 0.9 & 1.4 & 1.2 & 1.3 \\
\hline Other plastic resins & 1.0 & 0.0 & 0.0 & 0.8 & 0.3 & 0.7 & 0.7 & 1.3 & 0.0 & 0.0 \\
\hline Glass & 2.6 & 1.8 & 7.4 & 6.3 & 0.6 & 5.4 & 4.1 & 5.3 & 4.9 & 2.1 \\
\hline $\begin{array}{l}\text { Packaging container } \\
\text { glass }\end{array}$ & 2.6 & 1.8 & 7.4 & 4.7 & 0.6 & 5.4 & 4.1 & 5.3 & 4.9 & 2.1 \\
\hline Other/special glass & 0.0 & 0.0 & 0.0 & 1.7 & 0.0 & 0.0 & 0.0 & 0.0 & 0.0 & 0.0 \\
\hline Complex products & 3.3 & 4.7 & 5.5 & 4.7 & 3.3 & 4.4 & 8.6 & 11.5 & 4.6 & 4.1 \\
\hline $\begin{array}{l}\text { Composite/Complex } \\
\text { Packaging }\end{array}$ & 1.4 & 1.0 & 2.0 & 1.4 & 1.4 & 1.0 & 1.3 & 1.2 & 1.4 & 1.4 \\
\hline $\begin{array}{l}\text { Composite/other } \\
\text { Complex Packaging }\end{array}$ & 1.9 & 2.3 & 3.5 & 1.9 & 2.0 & 1.6 & 1.1 & 8.4 & 2.1 & 1.5 \\
\hline WEEE & 0.0 & 0.0 & 0.0 & 0.2 & 0.0 & 0.4 & 0.0 & 0.0 & 0.5 & 1.2 \\
\hline Mixed WEEE & 0.0 & 1.4 & 0.0 & 1.1 & 0.0 & 1.3 & 6.2 & 1.8 & 0.6 & 0.0 \\
\hline Textiles & 5.0 & 4.1 & 3.6 & 9.0 & 12.6 & 6.3 & 2.8 & 5.2 & 4.8 & 3.4 \\
\hline Non-clothing textiles & 0.0 & 0.0 & 0.0 & 0.0 & 0.0 & 0.0 & 0.0 & 5.2 & 0.0 & 0.0 \\
\hline Others textiles & 5.0 & 4.1 & 3.6 & 9.0 & 12.6 & 6.3 & 2.8 & 0.0 & 4.8 & 3.4 \\
\hline $\begin{array}{l}\text { Composites, } \\
\text { human hygiene } \\
\text { waste }\end{array}$ & 9.2 & 3.3 & 8.4 & 8.8 & 3.9 & 2.5 & 5.6 & 4.9 & 10.5 & 6.8 \\
\hline Metals & 1.1 & 1.6 & 2.3 & 1.5 & 2.4 & 2.0 & 2.5 & 4.0 & 2.3 & 0.9 \\
\hline Ferrous Packaging & 0.9 & 0.7 & 1.0 & 1.1 & 1.0 & 1.2 & 1.5 & 1.4 & 1.4 & 0.6 \\
\hline $\begin{array}{l}\text { Non-ferrous } \\
\text { Packaging }\end{array}$ & 0.2 & 0.9 & 1.3 & 0.1 & 0.5 & 0.0 & 0.0 & 1.3 & 0.0 & 0.3 \\
\hline $\begin{array}{l}\text { Miscellaneous } \\
\text { Ferrous }\end{array}$ & 0.0 & 0.0 & 0.0 & 0.3 & 0.0 & 0.7 & 1.0 & 0.7 & 0.0 & 0.0 \\
\hline Other metallic waste & 0.0 & 0.0 & 0.0 & 0.0 & 0.9 & 0.0 & 0.0 & 0.6 & 0.9 & 0.0 \\
\hline Wood & 0.8 & 0.0 & 0.0 & 0.0 & 1.3 & 0.0 & 1.0 & 1.5 & 0.0 & 0.0 \\
\hline Untreated Wood & 0.0 & 0.0 & 0.0 & 0.0 & 0.0 & 0.0 & 1.0 & 1.5 & 0.0 & 0.0 \\
\hline Other & 0.8 & 0.0 & 0.0 & 0.0 & 1.3 & 0.0 & 0.0 & 0.0 & 0.0 & 0.0 \\
\hline Special waste & 0.0 & 0.0 & 0.0 & 0.8 & 0.3 & 0.0 & 0.0 & 1.5 & 1.3 & 0.0 \\
\hline Quimical products & 0.0 & 0.0 & 0.0 & 0.2 & 0.0 & 0.0 & 0.0 & 0.0 & 0.0 & 0.0 \\
\hline Mixed WEEE & 0.0 & 0.0 & 0.0 & 0.2 & 0.0 & 0.0 & 0.0 & 0.8 & 0.7 & 0.0 \\
\hline $\begin{array}{l}\text { Single } \text { Batteries/non- } \\
\text { devicer } \\
\text { Batteries }\end{array}$ & 0.0 & 0.0 & 0.0 & 0.0 & 0.3 & 0.0 & 0.0 & 0.0 & 0.0 & 0.0 \\
\hline $\begin{array}{l}\text { Other household } \\
\text { hazardous waste }\end{array}$ & 0.0 & 0.0 & 0.0 & 0.4 & 0.0 & 0.0 & 0.0 & 0.7 & 0.6 & 0.0 \\
\hline $\begin{array}{l}\text { Gardening waste } \\
\text { (collect separately) }\end{array}$ & 15.6 & 7.5 & 8.4 & 2.5 & 16.0 & 7.1 & 14.6 & 13.3 & 6.6 & 2.6 \\
\hline Inert & 0.0 & 0.0 & 0.0 & 0.0 & 0.0 & 0.0 & 0.0 & 0.0 & 0.0 & 0.0 \\
\hline $\begin{array}{l}\text { Fines: } \quad<20 \mathrm{~mm} \\
\text { sieved fraction }\end{array}$ & 7.4 & 8.2 & 7.1 & 8.2 & 10.9 & 0.7 & 8.8 & 4.6 & 10.5 & 12.5 \\
\hline
\end{tabular}


Table 4. Composition per circuit between 13B-13A17and moloks routes

\begin{tabular}{|c|c|c|c|c|c|c|c|c|c|}
\hline Type & $\begin{array}{l}13 \mathrm{~B} \\
\%\end{array}$ & $\begin{array}{l}14 \mathrm{~A} \\
\%\end{array}$ & $\begin{array}{l}14 \mathrm{~B} \\
\%\end{array}$ & $\begin{array}{l}15 \mathrm{~B} \\
\%\end{array}$ & $\begin{array}{l}16 \mathrm{~B} \\
\%\end{array}$ & $\begin{array}{l}17 \\
\%\end{array}$ & $\begin{array}{l}\text { MS } 1 \\
\%\end{array}$ & $\begin{array}{l}\text { MS } 2 \\
\%\end{array}$ & $\begin{array}{l}\text { MS } 4 \\
\%\end{array}$ \\
\hline $\begin{array}{l}\text { Bio-degradable } \\
\text { waste }\end{array}$ & 39.5 & 34.8 & 23.9 & 43.6 & 44.3 & 41.6 & 44.8 & 46.2 & 47.9 \\
\hline Food waste & 11.0 & 4.6 & 4.6 & 2.1 & 6.2 & 15.7 & 7.3 & 11.9 & 13.2 \\
\hline Gardening waste & 3.0 & 2.5 & 6.0 & 0.5 & 9.5 & 0.0 & 3.1 & 2.4 & 7.7 \\
\hline $\begin{array}{l}\text { Other biodegradable } \\
\text { waste }\end{array}$ & 25.4 & 27.6 & 13.3 & 41.0 & 28.6 & 25.9 & 34.5 & 31.9 & 26.9 \\
\hline $\begin{array}{l}\text { Paper and } \\
\text { Cardboard }\end{array}$ & 6.8 & 10.8 & 6.9 & 12.4 & 17.1 & 22.6 & 9.4 & 7.4 & 11.3 \\
\hline $\begin{array}{l}\text { Paper/card } \quad \text { - } \\
\text { packaging }\end{array}$ & 2.2 & 1.0 & 4.4 & 2.2 & 5.5 & 6.9 & 5.8 & 2.1 & 1.4 \\
\hline $\begin{array}{l}\text { Newspapers and } \\
\text { magazines }\end{array}$ & 1.1 & 4.6 & 2.5 & 6.0 & 5.8 & 7.7 & 2.3 & 2.3 & 7.0 \\
\hline $\begin{array}{l}\text { Other Paper/card- } \\
\text { non packaging }\end{array}$ & 3.6 & 5.2 & 0.0 & 4.2 & 5.8 & 8.0 & 1.4 & 2.9 & 2.9 \\
\hline Plastics & 11.5 & 12.2 & 16.5 & 13.4 & 11.3 & 15.9 & 10.8 & 13.1 & 12.2 \\
\hline Plastic film PE & 6.7 & 8.2 & 8.5 & 8.2 & 6.3 & 10.4 & 6.1 & 8.3 & 7.3 \\
\hline $\begin{array}{l}\text { Packaging plastic } \\
\text { PET }\end{array}$ & 1.1 & 1.2 & 1.3 & 1.5 & 1.2 & 1.7 & 1.0 & 1.4 & 2.1 \\
\hline $\begin{array}{l}\text { Packaging plastic } \\
\text { PEAD }\end{array}$ & 1.8 & 1.5 & 1.8 & 1.1 & 2.6 & 1.6 & 1.7 & 2.0 & 1.4 \\
\hline $\begin{array}{l}\text { Packaging plastic } \\
\text { EPS }\end{array}$ & 0.3 & 0.0 & 0.5 & 0.1 & 0.0 & 0.2 & 0.5 & 0.2 & 0.0 \\
\hline $\begin{array}{l}\text { Non-packaging } \\
\text { plastic }\end{array}$ & 1.1 & 0.9 & 3.5 & 2.1 & 1.2 & 2.0 & 0.8 & 1.2 & 0.4 \\
\hline Other plastic resins & 0.4 & 0.4 & 0.9 & 0.5 & 0.0 & 0.0 & 0.6 & 0.0 & 1.0 \\
\hline Glass & 2.9 & 6.3 & 4.3 & 4.8 & 4.8 & 2.9 & 5.8 & 7.0 & 3.2 \\
\hline $\begin{array}{l}\text { Packaging container } \\
\text { glass }\end{array}$ & 2.9 & 6.3 & 4.3 & 4.8 & 4.8 & 2.9 & 5.8 & 7.0 & 3.2 \\
\hline Other/special glass & 0.0 & 0.0 & 0.0 & 0.0 & 0.0 & 0.0 & 0.0 & 0.0 & 0.0 \\
\hline Complex products & 3.9 & 5.7 & 4.8 & 4.3 & 3.6 & 3.4 & 6.1 & 3.2 & 2.7 \\
\hline $\begin{array}{l}\text { Composite/Comple } \\
\text { x Packaging }\end{array}$ & 0.8 & 1.1 & 2.2 & 1.9 & 1.2 & 0.9 & 1.9 & 1.1 & 1.3 \\
\hline $\begin{array}{l}\text { Composite/other } \\
\text { Complex Packaging }\end{array}$ & 0.8 & 1.7 & 0.8 & 1.6 & 2.4 & 2.5 & 2.2 & 1.2 & 0.7 \\
\hline WEEE & 0.5 & 2.9 & 0.0 & 0.0 & 0.0 & 0.0 & 0.0 & 0.0 & 0.0 \\
\hline Mixed WEEE & 1.8 & 0.0 & 1.7 & 0.8 & 0.0 & 0.0 & 2.0 & 0.9 & 0.7 \\
\hline Textiles & 3.0 & 7.7 & 3.0 & 5.4 & 5.5 & 0.0 & 5.4 & 2.2 & 3.6 \\
\hline $\begin{array}{l}\text { Non-clothing } \\
\text { textiles }\end{array}$ & 0.0 & 0.0 & 0.0 & 0.0 & 0.0 & 0.0 & 3.9 & 0.0 & 0.0 \\
\hline Others textiles & 3.0 & 7.7 & 3.0 & 5.4 & 5.5 & 0.0 & 1.5 & 2.2 & 3.6 \\
\hline $\begin{array}{l}\text { Composites, } \\
\text { human hygiene } \\
\text { waste }\end{array}$ & 2.8 & 4.9 & 3.8 & 7.6 & 4.4 & 2.2 & 0.0 & 5.2 & 7.7 \\
\hline Metals & 3.2 & 3.4 & 3.0 & 1.7 & 1.6 & 2.8 & 3.2 & 1.3 & 0.9 \\
\hline Ferrous Packaging & 1.7 & 1.4 & 0.8 & 1.1 & 1.6 & 1.5 & 2.0 & 1.3 & 0.5 \\
\hline $\begin{array}{l}\text { Non-ferrous } \\
\text { Packaging }\end{array}$ & 0.9 & 0.0 & 1.3 & 0.6 & 0.0 & 1.3 & 0.0 & 0.0 & 0.4 \\
\hline $\begin{array}{l}\text { Miscellaneous } \\
\text { Ferrous }\end{array}$ & 0.0 & 0.0 & 0.0 & 0.0 & 0.0 & 0.0 & 0.0 & 0.0 & 0.0 \\
\hline Other metallic waste & 0.6 & 2.0 & 0.9 & 0.0 & 0.0 & 0.0 & 1.2 & 0.0 & 0.0 \\
\hline Wood & 0.7 & 0.0 & 0.0 & 0.0 & 0.0 & 0.0 & 1.3 & 1.9 & 0.0 \\
\hline
\end{tabular}




\begin{tabular}{|c|c|c|c|c|c|c|c|c|c|}
\hline Type & $\begin{array}{l}13 \text { B } \\
\%\end{array}$ & $\begin{array}{l}14 \mathrm{~A} \\
\%\end{array}$ & $\begin{array}{l}14 \text { B } \\
\%\end{array}$ & $\begin{array}{l}15 \text { B } \\
\%\end{array}$ & $\begin{array}{l}16 \text { B } \\
\%\end{array}$ & $\begin{array}{l}17 \\
\%\end{array}$ & $\begin{array}{l}\text { MS } 1 \\
\%\end{array}$ & $\begin{array}{l}\text { MS } 2 \\
\%\end{array}$ & $\begin{array}{l}\text { MS } 4 \\
\%\end{array}$ \\
\hline Untreated Wood & 0.7 & 0.0 & 0.0 & 0.0 & 0.0 & 0.0 & 0.0 & 0.0 & 0.0 \\
\hline Other & 0.0 & 0.0 & 0.0 & 0.0 & 0.0 & 0.0 & 1.3 & 1.9 & 0.0 \\
\hline Special waste & 1.0 & 0.0 & 0.0 & 0.0 & 0.1 & 0.0 & 1.2 & 0.0 & 0.0 \\
\hline Quimical products & 0.4 & 0.0 & 0.0 & 0.0 & 0.1 & 0.0 & 0.6 & 0.0 & 0.0 \\
\hline Mixed WEEE & 0.0 & 0.0 & 0.0 & 0.0 & 0.0 & 0.0 & 0.6 & 0.0 & 0.0 \\
\hline $\begin{array}{l}\text { Single } \\
\text { Batteries/non- } \\
\text { device specific } \\
\text { Batteries }\end{array}$ & 0.0 & 0.0 & 0.0 & 0.0 & 0.0 & 0.0 & 0.0 & 0.0 & 0.0 \\
\hline $\begin{array}{l}\text { Other household } \\
\text { hazardous waste }\end{array}$ & 14.9 & 0.0 & 25.1 & 0.0 & 0.0 & 0.0 & 0.0 & 0.0 & 0.0 \\
\hline $\begin{array}{l}\text { Gardening waste } \\
\text { (collect separately) }\end{array}$ & 0.0 & 0.0 & 0.0 & 0.0 & 0.0 & 0.0 & 0.0 & 0.0 & 0.0 \\
\hline $\begin{array}{l}\text { Fines: } \quad<20 \mathrm{~mm} \\
\text { sieved fraction }\end{array}$ & 9.8 & 14.2 & 8.8 & 6.8 & 7.3 & 8.7 & 11.9 & 12.4 & 10.4 \\
\hline
\end{tabular}

Results evidence that the routes with major organic waste with $40.0 \%$ and $53.8 \%$ of the total MSW collected are 1B, 2B, 5A, 5B, 6B, 10A, 13A, 15B, 16B, 17, and moloks. Being all of them, mix or urban routes, which can be explain as the rural routes reuse the bio-degradable waste to the agriculture practices. The results indicate that the composition of organic waste is prevalent regarding biodegradable waste and food waste. The second large category in the waste stream are plastics, sharing a percentage between $9.0 \%$ and $17.0 \%$ of all MSW. Only two routes are below $10.0 \%$; The third most representative waste category is paper and cardboard, which is made up of paper packages (cardboard and combined packages) and prints (newspapers, magazines and books), this is valid for 18 routes that have shown a percentage of paper higher than $10 \%$ (of all MSW). This fact evidences the needs to create a new paper/and plastic route covering the entire Municipality. It also worth to be noticed that in route 3 a high percentage of glass was found $(24.3 \%)$. In order to understand the causes for this fact, results have to be studied independently. Another important remark is the fact that 30\% of the waste with potential to be recyclable, is still mixed in MSW. The textile material is very relevant as the major percentage corresponds to routes with containers, being a clue that the industries does not have private collect for these materials and simply put them where they find containers. A possibility to solve this problem is the creation of a specific route to textile collection on the principle small industries parks.

\section{Conclusion}

It was our goal to identify the routes that involve the higher percentages of recyclable waste, mixed in urban waste to following determine measures to maximize the recycling collection, in those areas, to target the objectives set in European and Portuguese legislation. The organic fraction, represent the highest share in the waste stream ranging from $15.0 \%$ to almost $50.0 \%$. Concerning the geographical locations recorded, the organic waste decreases from the rural circuits to urban and mix circuits. Plastic waste was the second highest fraction and the results are very similar in all routes. Paper waste also recorded a very high percentage. Solutions must be analyzed and 
designed to reduce these materials in MSW. This is an example which may influence the low recycling rate of MSW could be the extent of packaging waste from households and similar packaging from other sources which is included in HW. According to the results obtained from the MSW, a report will be conducted by CVR and solutions will be studied to raise the percentage of recycling materials of recycle collection and increase biodegradable waste in the MSW. This will be in line with the EU contend that Portugal needs to achieve in order to fulfill the 50\% recycling target of the Waste Framework Directive by 2020 (Reichel, 2013). At Guimarães, the method used for separation is commonly based on the use of different containers for glass, paper/cardboard, and plastic/metal, placed together at Ecopoints preferably located on the streets and in strategic points such as schools, parks, sport complexes, markets, fairs, and industries. According to Pina (2015), the higher percentage of people who recycle corresponds to the ones who have the Ecopoints less than $200 \mathrm{~m}$ of its habitations. Therefore, a strategy for the Municipality is required to increase the recycling in the door in door system, as almost $90.0 \%$ of the municipality has door in door system to HW.

\section{References}

Zotos, G., Karagiannidis, A., Zampetoglou, S., Malamakis, A., Antonopoulos, I-S, Kontogianni, S., Tchobanoglous, G., 2009. Developing a holistic strategy for integrated waste management within municipal planning: Challenges, policies, solutions and perspectives for Hellenic municipalities in the zero-waste, low-cost direction. Waste Management. 29 (2009), 1686-1692.

European Commission, European Green capital, 2015. Available online at: http://ec.europa.eu/environment/europeangreencapital/wpcontent/uploads/2016/01/egca_2018_application.pdf (Accessed march 15th, 2016).

Directive 2008/98/EC of the European Parliament and of the Council, of 18 november 2008. Available online at: http://eur-lex.europa.eu/legal-content/EN/TXT/?uri=CELEX:32008L0098 (Accessed march 15th, 2016).

Sahimaa, O., Hupponen, M., Horttanainen, M., Sorvari, J., 2015. Method for residual household waste composition studies. Waste Management. 46 (2015), 3-14.

Maria, F., Micale, C., 2014. A holistic life cycle analysis of waste management scenarios at increasing source segregation intensity: The case of an Italian urban a Waste Management. 34 (2014), 2382-2392.

Suthar, S., Singh, P., 2014. Household solid waste generation and composition in different familysize and socio-economic groups: A case study. Sustainable Cities and Society. 14 (2015), 56-63.

Portaria n. ${ }^{\circ}$ 851/2009, 07 de agosto. Aprova as normas técnicas relativas à caracterização de resíduos urbanos. Available online at: http://www.oern.pt/documentos/legislacao/portarias/P851_2009.pdf (Accessed march 18th, 2016).

Pina, S. (2015). Estudo da perceção ambiental da população do Concelho de Guimarães. Relatório de Estágio da Licenciatura em Estatística Aplicada Estudo da perceção ambiental. Escola de Ciência, Universidade do Minho, Portugal.

Das, S., Bhattacharyya, B., Optimization of municipal solid waste collection and transportation routes. Waste Management. 43 (2015), 9-18.

Bovea, M.D., Ibanez-Fores, V., Gallardo, A., Colomer-Mendoza, F.J., 2010. Environmental assessment of alternative municipal solid waste management strategies. A Spanish case study. Waste Management. 30 (11), 2383-2395.

Gallardo, A., Carlos, M., Peris, M., Colomer, F.J., 2015. Methodology to design a municipal solid waste precollection system. A case study. Waste Management. 36, 1-11.

Dyson, B., Chang, N.B., 2005. Forecasting municipal solid waste generation in a fastgrowing urban region with system dynamics modeling. Waste Management. 25, 669-679. 
Beigl, P., Sandra, L., Stefan, S., 2008. Modelling municipal solid waste generation: A review. Waste Management. 28, 200-214.

Edjabou, E., Jensen, B., Götze, R., Pivnenko, K., Petersen, C., Scheutz, C., Astrup, F., 2015. Municipal solid waste composition: Sampling methodology, statistical analyses, and case study evaluation. Waste Management. 36, 12-23.

Gómez, G., Meneses, M., Ballinas, L., Castells, F., 2009. Seasonal characterization of municipal solid waste (MSW) in the city of Chihuahua, Mexico. Waste Management. 29, 2018-2024.

Zaman, A., Lehmann, S., 2011. Urban growth and waste management optimization towards 'zerowaste city'. City Culture and Society. 2, 177-187.

Magrinho, A., Didelet, F., Semiao, V., 2006. Municipal solid waste disposal in Portugal. Waste Management. 26, 1477-1489.

Lisa, D., Anders, L., 2008. Methods for household waste composition studies. Waste Management. 28, $1100-1112$.

Instituto Nacional de Estatística (INE), Tipologia de áreas urbanas, 2014, file:///C:/Users/UTILIZADOR/Downloads/TIPAU_2014_Relat\%C3\%B3rio\%20T\%C3\%A9c nico.pdf (Accessed may 18th, 2016).

European Commission, European, 2004. Methodology for the Analysis of Solid Waste (SWA-Tool) User. Version Available online at: https://www.wien.gv.at/meu/fdb/pdf/swa-tool-759-ma48.pdf (Accessed april 15th, 2016).

WastesWork and AEA, 2010. The composition of municipal solid waste in Wales - final report. Version Available online

at: http://www.wrapcymru.org.uk/sites/files/wrap/Wales_compositional_analysis_report_2_.9076. pdf (Accessed may 05th, 2016).

Reichel, A., (2013). Municipal waste management in Portugal. European Environment Agency. Available online file:///C:/Users/UTILIZADOR/Downloads/Portugal MSW\%20(1).pdf (Accessed may 05th, 2016) 